\title{
The Diffusion of Tc-99 in Beishan Granite-Temperature Effect*
}

\author{
C. Li ${ }^{1,2}$, Z. Zheng ${ }^{1}$, X. Y. Liu ${ }^{1}$, T. Chen ${ }^{1,3}$, W. Y. Tian ${ }^{1}$, \\ L. H. Wang ${ }^{1}$, C. L. Wang ${ }^{1}$, C. L. Liu ${ }^{1 \#}$ \\ ${ }^{1}$ Beijing National Laboratory for Molecular Science, Radiochemistry \& Radiation Chemistry Key Laboratory for Fundamental \\ Science, College of Chemistry and Molecular Engineering, Peking University, Beijing, China \\ ${ }^{2}$ State Nuclear Security Technology Center, Beijing, China \\ ${ }^{3}$ North China Electric Power University, Beijing, China \\ Email: " liucl@pku.edu.cn
}

Received October 12, 2012; revised November 21, 2012; accepted December 13, 2012

\begin{abstract}
In the safety assessment of a potential site for high-level radioactive wastes (HLW) disposal, the investigation on the geochemical behaviors of key radionuclides with the possibility for releasing from the potential repository is an important aspect. Due to the high mobility of technetium under most repository conditions, lots of research works were performed to investigate the diffusion of technetium in different potential rocks. In spite of these studies, there remains a lack of data addressing temperature effects. In this paper, the diffusion of ${ }^{99} \mathrm{Tc}$ in Beishan granite at temperatures from $25^{\circ} \mathrm{C}$ to $55^{\circ} \mathrm{C}$ was studied with laboratory small scale diffusion devices. The experimental data were fitted with a finite difference scheme to get the effective diffusion coefficient (De) of ${ }^{99} \mathrm{TcO}_{4}^{-}$. The results indicated that the relationship of De with temperatures could be described as the modified Stokes-Einstein equation, and the formation factor of Beishan granite was constant in the temperature range of $25^{\circ} \mathrm{C}-55^{\circ} \mathrm{C}$ with the value of $(3.91 \pm 1.77) \times 10^{-4}$.
\end{abstract}

Keywords: Diffusion; Technetium; Beishan Granite; Temperature Effect

\section{Introduction}

Safety disposal of high-level radioactive wastes (HLW) is a worldwide challenge of nuclear industry. Deep geological disposal is the most acceptable way in isolating the HLW from biosphere. To demonstrate that the wastes can be safely isolated from the biosphere in a long time scale which is needed for the HLW radioactivity decays to natural level, the safety assessment of the geologic repository is an essential task. In the safety assessment of a potential site for HLW disposal, investigation on the geochemical behaviors of key radionuclides with the possibility for releasing from the potential repository is an important aspect. It is well understood that after the placement of HLW into the repository, the wastes will release considerable amount of heat due to the decay of radionucludes in a period of 100 years. The temperature of the HLW container will be rised up to $90^{\circ} \mathrm{C}$ [1-3] or

\footnotetext{
*The project was jointly supported by the National Natural Science Foundation of China (Grant No. 10775008, 11075006, 91026010), Research Fund for Ph.D. Program of the Ministry of Education (20060001032), Special Foundation for High-level Waste Disposal (2007-840), the Fundamental Research Funds for the Central Universities, Analysis foundation of Peking University (13-18) and the 111 projects.

${ }^{\#}$ Corresponding author.
}

even higher. Naturally, the temperatures of the surrounding backfilling materials and the host rock in the near field will also be increased. The rising temperature increases the solubility and diffusion coefficient of contaminants (radionuclides) in most cases, while lowering the viscosity, density of the groundwater, and the sorption coefficient of radionuclides $[4,5]$. So that the migration of radionuclides in the near field will be enhanced $[6,7]$. The effects of temperature on fluid density and viscosity are well understood, and equations describing those effects are readily available $[8,9]$. In general, temperature increase leads to decreasing in both water density and viscosity, which induces buoyant groundwater flow, and faster mass transport [10]. But there remains a lack of data addressing the temperature effects on radionuclide diffusion and migration in natural rock/water systems.

In China, Beishan granite area in Gansu province has been pre-selected as one of the most potential research site for HLW repository [11]. Started from 1985, many research works have been performed in regard to site investigation, geologic survey, groundwater chemistry, core sample drilling, as well as radionuclide transport experiments [12-14]. For example, Lu et al. investigated 
the diffusion of ${ }^{125} \mathrm{I}^{-}$as a surrogate for ${ }^{129} \mathrm{I}^{-}$in Beishan granite obtained at 300-m depth by laboratory diffusion experiments, and the results showed that the effective diffusion coefficient ranged from $2.44 \times 10^{-12}$ to $2.72 \times$ $10^{-12} \mathrm{~m}^{2} / \mathrm{s}$ [15]. After this work, Chen et al. investigated the influence of temperature on ${ }^{125} \mathrm{I}^{-}$diffusion in $600-\mathrm{m}$ deep Beishan granite, and found that the relationship between the effective diffusion coefficient and temperature could be described by the modified Nernst equation at $27^{\circ} \mathrm{C}-50^{\circ} \mathrm{C}$ [16]. That was the first effort of our group in temperature effects for radionuclide diffusion. Like ${ }^{125} \mathrm{I},{ }^{99} \mathrm{Tc}$ is one of the most important fission products in the spent fuels from nuclear power plants, due to its high mobility and long half-life [17-25]. Its diffusion and migration data are important to the data base for performance assessment of the potential geologic repository, while the temperature effect on the diffusion of ${ }^{99} \mathrm{Tc}$ in host rocks has not yet been reported. In this work, the temperature effect on its diffusion in Beishan granite was investigated by through-diffusion method.

\section{Experimental}

\subsection{Materials}

A Beishan granite core sample was drilled out in the depth of about $600 \mathrm{~m}$ at Beishan area, in Northwest China's Gansu province, China. The core sample was cut into slices which were $64 \mathrm{~mm}$ in diameter and $5 \mathrm{~mm}$ in thickness. Another small fraction of the same granite core sample was crushed and sieved by 200 mesh sieves to get granite powder sample, which was used for characterization. The mineralogical composition of the granite sample was determined by the XRD method, and the data is given in Table 1. The chemical and elemental composition of the granite sample which is characterized by an X-ray fluorescence spectrometer (XRFS) (ARL ADVANT XP+, Thermo electron co.) is given in Table 2. The porosity values of the granite slices were measured by water immersion technique [15-17]. Table 3 shows the physical parameters of the granite slices. ${ }^{99} \mathrm{Tc}$ was in the form of $\mathrm{NH}_{4} \mathrm{TcO}_{4}$ (Eckert \& Ziegler Isotope). All other chemicals were in AR grade and bought from Sinopharm Chemical Reagent Co.

\subsection{Through-Diffusion Experiments}

The through-diffusion technique was used to investigate the diffusion of ${ }^{99} \mathrm{Tc}$ in Beishan granite. The diffusion device was described in detail in previous work and is schematically shown in Figure 1. It consisted of a large source cell (ca. $1800 \mathrm{~mL}$ ) and a small sample cell (ca. 70 $\mathrm{mL}$ ). A granite slice (cross section area: $24.9 \pm 0.4 \mathrm{~cm}^{2}$; thickness $0.5 \mathrm{~cm}$ ) was mounted between the two cells. The cells were filled with a $0.1 \mathrm{M} \mathrm{NaClO}_{4}$ solution. The hydraulic heads in the two cells were kept the same during the experiment. A small amount of ${ }^{99}$ Tc (ca. 0.02 $\mathrm{mCi}$ ) was added as $\mathrm{TcO}_{4}^{-}$to the source cell. After mixing for 24 hours, one $\mathrm{mL}$ solution was taken from each cell and assayed for ${ }^{99} \mathrm{Tc}$ by liquid scintillation counting (TriCarb 3110 TR, Perkin Elmer) using 10 mL of scintillation cocktail (Optiphase Hisafe 2, Perkin Elmer). The counting efficiency of ${ }^{99} \mathrm{Tc}$ was $54.9 \%$. The specific activity of Tc in the source cell was $(5.0 \pm 0.1) \times 10^{2} \mathrm{~Bq} / \mathrm{L}$. The one milliliter sample removed from both cells was

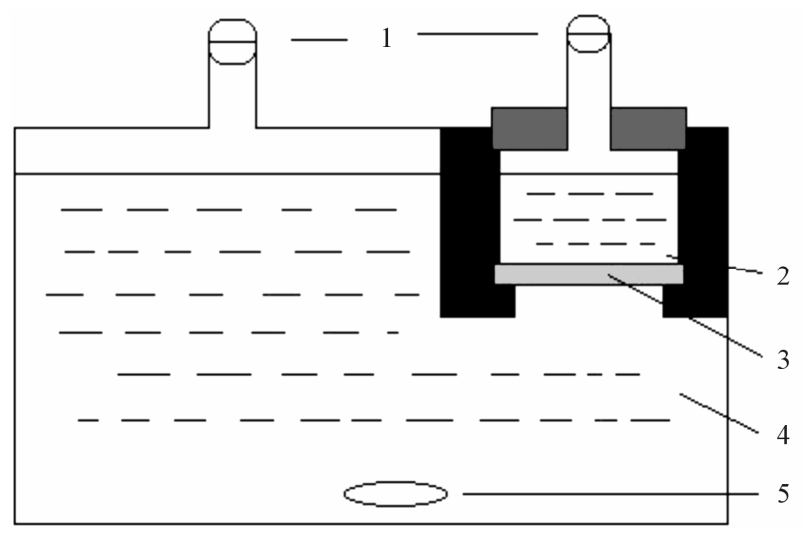

Figure 1. Set-up of the diffusion cell. 1: Sealing caps; 2: Sampling cell; 3: Granite slice; 4: Source cell; 5: Stirring bar.

Table 1. Mineralogical composition of 600-m deep Beishan granite (\%).

\begin{tabular}{cccccc}
\hline Microcline & Albite & Biotite & Quartz & Cordierite & Amesite \\
\hline 46.14 & 27.50 & 15.65 & 8.50 & 1.33 & 0.89 \\
\hline
\end{tabular}

Table 2. Chemical and elemental composition of Beishan granite (\%)

\begin{tabular}{cccccccccccc}
\hline $\mathrm{SiO}_{2}$ & $\mathrm{Al}_{2} \mathrm{O}_{3}$ & $\mathrm{~K}_{2} \mathrm{O}$ & $\mathrm{Fe}_{2} \mathrm{O}_{3}$ & $\mathrm{CaO}$ & $\mathrm{Na}_{2} \mathrm{O}$ & $\mathrm{MgO}$ & $\mathrm{P}_{2} \mathrm{O}_{5}$ & $\mathrm{TiO}_{2}$ & $\mathrm{SrO}^{2}$ & $\mathrm{LOI}^{a}$ \\
57.78 & 15.42 & 6.15 & 4.07 & 3.25 & 2.54 & 2.12 & 0.96 & 0.79 & 0.13 & 6.45 \\
$\mathrm{O}$ & $\mathrm{Si}$ & $\mathrm{Al}$ & $\mathrm{K}$ & $\mathrm{Fe}$ & $\mathrm{Ca}$ & $\mathrm{Na}$ & $\mathrm{Mg}$ & $\mathrm{P}_{x}$ & $\mathrm{Ti}$ & $\mathrm{LOI}^{\mathrm{a}}$ \\
43.66 & 27.01 & 8.16 & 5.10 & 2.85 & 2.32 & 1.88 & 1.28 & 0.42 & 0.48 & 6.45 \\
\hline
\end{tabular}

${ }^{\mathrm{a}}$ Loss of ignition. 
Table 3. Physical parameters of the granite slices.

\begin{tabular}{cccccc}
\hline Temperature $\left({ }^{\circ} \mathrm{C}\right)$ & Dry density $\left(\mathrm{g} / \mathrm{cm}^{3}\right)$ & Porosity $(\%)$ & $D_{e}\left(10^{-12} \mathrm{~m}^{2} / \mathrm{s}\right)$ & $K_{d}\left(10^{-3} \mathrm{~L} / \mathrm{kg}\right)$ & $F_{f}$ \\
\hline 25 & $2.63 \pm 0.02$ & $0.54 \pm 0.02$ & $0.70 \pm 0.27$ & $5.7 \pm 1.1$ & $(3.61 \pm 1.36) \times 10^{-4}$ \\
32 & $2.58 \pm 0.02$ & $0.64 \pm 0.04$ & $0.91 \pm 0.28$ & $8.1 \pm 2.8$ & $(3.94 \pm 1.20) \times 10^{-4}$ \\
35 & $2.63 \pm 0.02$ & $0.54 \pm 0.03$ & $1.03 \pm 0.44$ & $7.4 \pm 2.7$ & $(4.13 \pm 1.77) \times 10^{-4}$ \\
40 & $2.63 \pm 0.01$ & $0.67 \pm 0.05$ & $1.06 \pm 0.23$ & $6.1 \pm 2.3$ & $(3.80 \pm 0.84) \times 10^{-4}$ \\
45 & $2.57 \pm 0.01$ & $0.66 \pm 0.05$ & $1.25 \pm 0.33$ & $7.5 \pm 1.6$ & $(4.05 \pm 1.07) \times 10^{-4}$ \\
50 & $2.61 \pm 0.03$ & $0.56 \pm 0.04$ & $1.31 \pm 0.34$ & $7.0 \pm 1.8$ & $(3.80 \pm 0.97) \times 10^{-4}$ \\
55 & $2.61 \pm 0.02$ & $0.69 \pm 0.03$ & $1.54 \pm 0.36$ & $9.7 \pm 0.4$ & $(4.05 \pm 0.96) \times 10^{-4}$ \\
Average & $2.61 \pm 0.03$ & $0.61 \pm 0.07$ & $/$ & $/$ & $(3.91 \pm 1.77) \times 10^{-4}$ \\
\hline
\end{tabular}

replaced by one milliliter of $0.1 \mathrm{M} \mathrm{NaClO}_{4}$ after each sampling.

Before the start of the experiments, $0.1 \mathrm{~mol} / \mathrm{L} \mathrm{NaClO}_{4}$ solution was added into both the source and the sample cell. The hydraulic heads in the two cells were kept the same by monitoring the water levels in the cells and fresh $0.1 \mathrm{~mol} / \mathrm{L} \mathrm{NaClO}_{4}$ solution was added when needed. Then a dose $(\sim 0.02 \mathrm{mCi})$ of ${ }^{99} \mathrm{Tc}$ solution was added into the source cell. After stirring for 24 hours, $1.0 \mathrm{~mL}$ solution was taken from each cell and mixed with $10.0 \mathrm{~mL}$ scintillation cocktail (Optiphase Hisafe 2, Perkin Elmer) for radioactivity measurement with a Liquid Scintillation Counter (Tri-Carb 3110TR, Perkin Elmer). The counting efficiency of ${ }^{99} \mathrm{Tc}$ was $54.9 \%$. The specific activity of ${ }^{99} \mathrm{Tc}$ in the source cell was measured as $(5.0 \pm 0.1) \times 10^{2}$ into each cell. The activity of ${ }^{99} \mathrm{Tc}$ in the sample cell was measured in the same way at a 2-day interval in the first 10 days and in a 4-day interval in the rest of the 81-day experiment.

\section{Model Description}

As all of our experiments were performed under atmospheric condition, ${ }^{99} \mathrm{Tc}$ could not be reduced into lower oxidation state and stayed as ${ }^{99} \mathrm{TcO}_{4}^{-}$during the experiment $[26,27]$. Since the concentration of ${ }^{99} \mathrm{Tc}$ in the sample cell was diluted after each sampling due to the replacement of $1.0 \mathrm{~mL}$ water sample with $1.0 \mathrm{~mL} \mathrm{Na}$ $\mathrm{ClO}_{4}$ solution, the experimental data were corrected with the method used in our previous work $[15,16]$. The radioactive decay of ${ }^{99} \mathrm{Tc}$ can be ignored, due to its long half life of $2.1 \times 10^{5} \mathrm{y}$.

According to the set up of our experiment, the diffusion of radionuclide in the diffusion cell could be described by the decreasing inlet concentration-increasing outlet concentration through-diffusion model (DC-IC) or approximately by the constant inlet concentration-increasing outlet concentration through-diffusion model (CC-IC), and the diffusion of ${ }^{99} \mathrm{Tc}$ in the granite can be described as [28,29]:

$$
\begin{aligned}
& \frac{\partial C(x, t)}{\partial t}=\frac{D_{e}}{\alpha} \frac{\partial^{2} C(x, t)}{\partial x^{2}} \\
& \alpha=\varepsilon+\rho K_{d}
\end{aligned}
$$

where $C(x, t)[\mathrm{cpm} / \mathrm{mL}]$ is the pore water concentration of ${ }^{99} \mathrm{Tc}$ in the granite at the time $t[\mathrm{~s}]$ and at position $x$ along the diffusion direction; $D_{e}\left[\mathrm{~m}^{2} / \mathrm{s}\right]$ is the effective diffusion coefficient of ${ }^{99} \mathrm{Tc}$ in the granite; $\varepsilon, \rho\left[\mathrm{kg} / \mathrm{dm}^{3}\right]$ are the porosity and dry bulk density of the granite sample.

According to the experimental set up, Equation (1) subjects to the following initial and boundary conditions [29]:

$$
\begin{gathered}
\text { I.C. }\left.C(x, t)\right|_{t=0}=\left\{\begin{array}{cc}
0, & 0<x \leq L \\
C_{0}, & x=0
\end{array}\right. \\
\text { B.C. } \frac{V_{u}}{D_{e} A} \frac{\partial C_{u}(t)}{\partial t}+\left.\frac{\partial C(x, t)}{\partial x}\right|_{x=0}=0 \\
\frac{V_{d}}{D_{e} A} \frac{\partial C_{d}(t)}{\partial t}-\left.\frac{\partial C(x, t)}{\partial x}\right|_{x=L}=0
\end{gathered}
$$

where $L[\mathrm{~m}]$, and $A\left[\mathrm{~m}^{2}\right]$ are the thickness and effective diffusion area of the granite sample, respectively; $V_{u}\left[\mathrm{~m}^{3}\right]$ and $V_{d}\left[\mathrm{~m}^{3}\right]$ are the volume of the source and sample cell, respectively; $C_{0}[\mathrm{cpm} / \mathrm{mL}]$ is the initial concentration of ${ }^{99} \mathrm{Tc}$ in the source cell. $C_{u}(t)[\mathrm{cpm} / \mathrm{mL}]$ and $C_{d}(t)$ $[\mathrm{cpm} / \mathrm{mL}]$ are the concentration of ${ }^{99} \mathrm{Tc}$ in the source and sample cell when the experiment lasts for time $t$ [s], equals to $C(0, t)$ and $C(L, t)$ in value, respectively. Since $V_{u} \square V_{d}$, the decrease of $C_{u}$ can be ignored.

In order to obtain the effective diffusion coefficient $D_{e}$, the experimental data were fitted with Equation (1) by a finite difference scheme. We assumed:

$$
\begin{gathered}
\frac{\partial C}{\partial t} \approx \frac{C(i, j+1)-C(i, j)}{\Delta t} \\
\frac{\partial C}{\partial x} \approx \frac{C(i+1, j)-C(i-1, j)}{2 \Delta x}
\end{gathered}
$$




$$
\frac{\partial^{2} C}{\partial x^{2}} \approx \frac{C(i+1, j)-2 C(i, j)+C(i-1, j)}{(\Delta x)^{2}}
$$

Then Equation (1) could be transformed into:

$$
\begin{aligned}
C(i, j+1)= & \left(\frac{D_{e} \Delta t}{\alpha(\Delta x)^{2}}\right) C(i+1, j) \\
& +\left(1-\frac{2 D_{e} \Delta t}{\alpha(\Delta x)^{2}}\right) C(i, j) \\
& +\left(\frac{D_{e} \Delta t}{\alpha(\Delta x)^{2}}\right) C(i-1, j)
\end{aligned}
$$

When $\Delta t$ and $\Delta x$ are chosen to satisfy the following condition, Equation (8) will have a stable numerical solution:

$$
\frac{D_{e} \Delta t}{\alpha(\Delta x)^{2}}<0.5
$$

For each experiment, we got the $D_{e}$ and $K_{d}$ by solving the equation set of Equation (2)-(4), (8) when $L, A, V_{u}, V_{d}$, $C_{0}$ and $C_{d}(t) / C_{0}$ at different temperatures are given. Figure 2 shows the fitting result of one of the diffusion experiment. Figure 2 indicates that the model fit our experimental data well.

\section{Results and Discussions}

The $D_{e}$ and $K_{d}$ values of ${ }^{99} \mathrm{Tc}^{-}$in Beishan granite at different temperatures are listed in Table 3. The $D_{e}$ value obtained at room temperature is comparable to the data reported in literatures (Table 4) $[17,18,30]$. The results show that the $K_{d}$ values do not significantly change with temperature, but that the $D_{e}$ values do. In our previous work, it was found that the relationship between the effective diffusion coefficients of ${ }^{125} \mathrm{I}^{-}$in the Beishan granite with temperature could be described by modified Nernst equation [16]. Following the same method to understand the temperature effect of ${ }^{99} \mathrm{Tc}$, the limit ionic equivalent conductivity of ${ }^{99} \mathrm{TcO}_{4}^{-}$at different temperatures was needed. Since there was no such data in the literature, the relation between the $D_{e}$ and the temperature of ${ }^{99} \mathrm{Tc}$ should be discussed in a new way.
Since the diffusion of a solute in a porous media is related to the tortuosity $(\tau)$ and contrictivity $(\delta)$ of the pores, the porosity $(\varepsilon)$ of the media and the self-diffusion coefficient of the solute $\left(D_{w}\right)$ which describes its diffusion behavior in free water [16], the effective diffusion coefficient $\left(D_{e}\right)$ of the solute is described as:

$$
D_{e}=\varepsilon \frac{\delta}{\tau^{2}} D_{w}=F_{f} D_{w}
$$

As $\delta$ and $\tau$ is hardly measured individually with experiments, the formation factor $F_{f}$ is carried out to describe the relation between $D_{e}$ and $D_{w} . F_{f}$ equls to $\varepsilon \delta / \tau^{2}$ and only depends on the inner structure of the porous media [31]. According to the explanation of the Brownian motion by Einstein, the self-diffusion coefficient of the solute $D_{w}$ depends on temperature [32]:

$$
D_{w}=k T / \zeta
$$

where $k[\mathrm{~J} / \mathrm{K}]$ is the Boltzmann constant, $\zeta[\mathrm{kg} / \mathrm{s}]$ is the friction constant. For a spherical solute particle larger than the particles of the solvent, $\zeta$ is taken approximately as the friction term in Stokes' law, $\zeta=6 \pi \eta r_{i}$, where $\eta$ $\left[\mathrm{kg} \cdot \mathrm{m}^{-1} \cdot \mathrm{s}-1\right]$ is the viscosity of the solvent and $r_{i}[\mathrm{~m}]$ is the radius of the particle of the solute. Then Equation (11) is

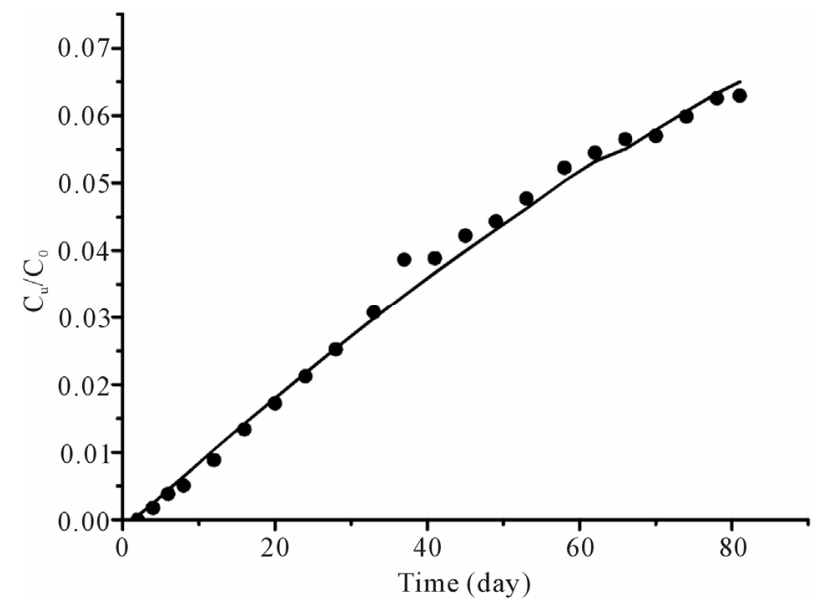

Figure 2. Breakthrough curve of the diffusion of ${ }^{99} \mathrm{Tc}$ in Beishan Granite at $40^{\circ} \mathrm{C}$. Solid circles are experimental data and the solid line is the fitting curve with decreasing inlet concentration-increasing outlet concentration through-diffusion model.

Table 4. $D_{e}$ and $K_{d}$ of ${ }^{99} \mathrm{TcO}_{4}^{-}$in Beishan granite in comparison with literature data.

\begin{tabular}{cccc}
\hline Reported by & Granite & Conditions & $D_{e}\left(10^{-12} \mathrm{~m}^{2} / \mathrm{s}\right)$ \\
This work & Beishan granite & $0.1 \mathrm{~mol} \cdot \mathrm{L}^{-1} \mathrm{NaClO}_{4}$ & $0.70 \pm 0.27$ \\
Liu et al. $[18]$ & Beishan granite & Simulated groundwater $(\mathrm{pH}=8.84)$ & $0.499-0.943$ \\
Liu et al. $[17]$ & Chinese granite & Groundwater & $0.118-0.315$ \\
Bradbury et al. $[30]$ & English granite & $\mathrm{KNO}_{3}$ & 1.4 \\
\hline
\end{tabular}


transformed into Stokes-Einstein equation:

$$
D_{w}=k T / 6 \pi \eta r_{i}
$$

In this work, ${ }^{99} \mathrm{Tc}$ was in the form of ${ }^{99} \mathrm{TcO}_{4}^{-}$, which could be taken as a spherical particle (close to the size of $\left.\mathrm{I}^{-}, r=2.16 \AA\right)$ and definitely larger than the water molecular $(r=1.4 \AA)$. Therefore the Stokes-Einstein equation can be used to describe the diffusion of ${ }^{99} \mathrm{TcO}_{4}^{-}$in water. Substituting Equation (12) into Equation (10), the following relation between $D_{e}$ and temperature is obtained:

$$
D_{e}=F_{f} k T / 6 \pi \eta r_{i}=F_{f}\left(\frac{k}{6 \pi r_{i}}\right)\left(\frac{T}{\eta}\right)
$$

In Equation (13), the viscosity of water $\eta$ is changed with temperature. The data of $\eta$ in the temperature range in this study are taken from Lange's handbook of chemistry, 13th edition and listed in Table 5 [33]. The experimental data showed that the ratio of $D_{e}$ and $T / \eta$ was constant (see Figure 3), which suggested that the formation factor $F_{f}$ of the Beishan granite was constant in the temperature range. $\mathrm{H}$. Sato et al. measured the $D_{w}$ value of ${ }^{99} \mathrm{TcO}_{4}^{-}$at $25^{\circ} \mathrm{C}$ as $(1.95 \pm 0.56) \times 10^{-9} \mathrm{~m}^{2} / \mathrm{s}$ [34]. From Equation (12), the $D_{w}$ value of ${ }^{99} \mathrm{TcO}_{4}^{-}$at the corresponding temperature was calculated. So $F_{f}$ of Beishan granite could be derived by dividing $D_{e}$ with $D_{w}$. The results were listed in Table 3 and shown in Figure 4. Figure 4 indicated that the formation factor of Beishan granite was nearly constant in the temperature range. This was in a good agreement with our previous work with ${ }^{125} \mathrm{I}^{-}$[16]. The $F_{f}$ values we obtained in this work are comparable to the literature data (Table 6) $[16,35]$, but higher than our previous work. The difference in $F_{f}$ may due to the difference in $D_{e}$ values of ${ }^{99} \mathrm{TcO}_{4}^{-}$obtained in this work $\left(7.4 \times 10^{-13}-1.4 \times 10^{-12} \mathrm{~m}^{2} / \mathrm{s}\right)$ to ${ }^{125} \mathrm{I}^{-}$ obtained in our previous work $\left(3.4 \times 10^{-13}-5.3 \times 10^{-13}\right.$ $\mathrm{m}^{2} / \mathrm{s}$ ), which was caused by the characteristics of the granite slices and the different diffusion behaviors of ${ }^{99} \mathrm{TcO}_{4}^{-}$and ${ }^{125} \mathrm{I}^{-}$in the granite.

Table 5. Viscosity of water at different temperatures [33].

\begin{tabular}{cc}
\hline Temperature $\left({ }^{\circ} \mathrm{C}\right)$ & Viscosity $(\mathrm{mPa} \cdot \mathrm{s})$ \\
\hline 25 & 0.8903 \\
32 & $0.7679^{\mathrm{a}}$ \\
35 & 0.7190 \\
40 & 0.6526 \\
45 & 0.5972 \\
50 & 0.5468 \\
55 & 0.5042 \\
\hline
\end{tabular}

${ }^{a}$ Calculated from the viscosity values at other temperatures by fitting the viscosity-temperature curve.

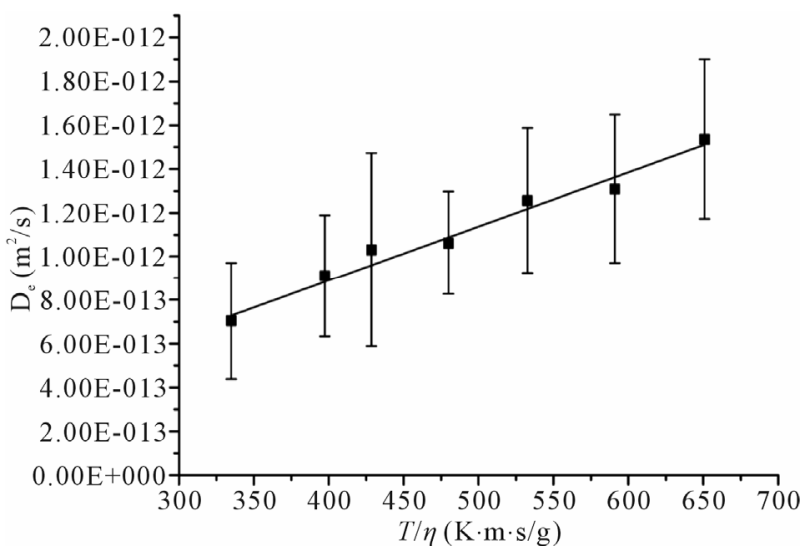

Figure 3. Effective diffusion coefficient $D_{e}$ of ${ }^{99} \mathrm{Tc}$ in Beishan granite as a function of $T / \eta$.

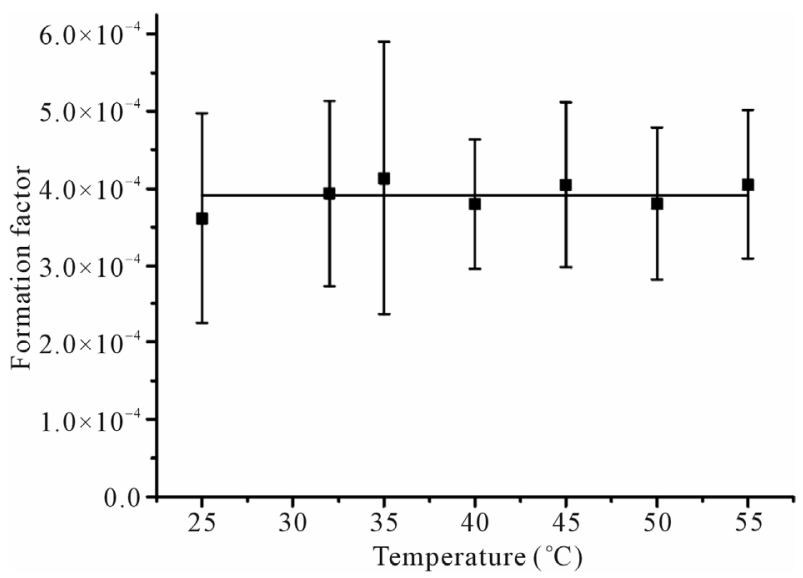

Figure 4. Formation factor of Beishan granite at the temperatures in this work.

Table 6. Formation factors of Beishan granite compared with literature data.

\begin{tabular}{ccc}
\hline Reported by & Granite & $\log F_{f}$ \\
\hline & Forsmark, granodiorite & $-3.58 \pm 0.31$ \\
Simpervarp, granite & $-4.52 \pm 0.91$ \\
SKB [35] & Laxemar, granite & $-3.86 \pm 0.31$ \\
& Sweden, granite & $-4.06 \pm 0.44$ \\
& Sweden, crystalline rock & $-4.15 \pm 0.45$ \\
& International, crystalline rock & $-3.72 \pm 0.47$ \\
Our previous work [16] & Forsmark, granodiorite & $-3.58 \pm 0.31$ \\
This work & Beishan granite & -3.99 \\
& Beishan granite & $-3.41 \pm 0.26$ \\
\hline
\end{tabular}

The constant formation factor of Beishan granite indicated that the inner structure of the granite did not change in the temperature range of $25^{\circ} \mathrm{C}-55^{\circ} \mathrm{C}$. This is very important for the granite as a host rock for the po- 
tential geologic repository. The enhanced diffusion of ${ }^{99} \mathrm{TcO}_{4}^{-}$in Beishan granite at higher temperatures were come from the increasing of $D_{w}$ of ${ }^{99} \mathrm{TcO}_{4}^{-}$.

\section{Conclusion}

The effect of temperature on diffusion of ${ }^{99} \mathrm{TcO}_{4}^{-}$in Beishan granite was studied using the through-diffusion technique. It was indicated that the effective diffusion coefficient of ${ }^{99} \mathrm{TcO}_{4}^{-}$in Beishan granite was linearly related with $T / \eta$ in the temperature range of $25^{\circ} \mathrm{C}-55^{\circ} \mathrm{C}$. The formation factor of Beishan granite was constant in the temperatures range, which suggested that the inner structure of Beishan granite did not change in the temperature range. The result of this work was in good agreement with our previous work except that the value of $F_{f}$ is larger. The difference of $F_{f}$ could be considered as experiment uncertainty. The result indicated Beishan granite was stable below $55^{\circ} \mathrm{C}$ and appropriate to be a host rock.

\section{REFERENCES}

[1] D. G. Bennett and R. Gens, "Overview of European Concepts for High-Level Waste and Spent Fuel Disposal with Special Reference Waste Container Corrosion," Journal of Nuclear Materials, Vol. 379, No. 1-3, 2008, pp. 1-8. doi:10.1016/j.jnucmat.2008.06.001

[2] H. Hökmark and B. Fälth, "Thermal Dimensioning of the Deep Repository," 2003, p. 83.

[3] T. Tarandi, "Calculated Temperature Field in and around Repository for Spent Nuclear Fuel," KBS Teknisk Rapport, Vol. 83, No. 22, 1983, p. 32.

[4] B. B. Looney and R. W. Falta, "Vadose Zone: Science and Technology Solutions," Battelle Press, Columbus, 2000.

[5] J. R. Boulding and J. S. Ginn, "Practical Handbook of Soil, Vadoze Zone and Groundwater Contamination, Assessment, Prevention, and Remediation," A. F. Lewis, New York, 2004.

[6] F. G. Sanchez, L. R. Van Loon, T. Gimmi, et al., "SelfDiffusion of Water and Its Dependence on Temperature and Ionic Strength in Highly Compacted Montmorillonite, Illite and Kaolinite," Applied Geochemistry, Vol. 23, No. 12, 2008, pp. 3840-3851.

doi:10.1016/j.apgeochem.2008.08.008

[7] A. V. Simonyan, H. Behrens and S. Dultz, "Diffusive Transport of Water in Porous Feldspars from Granitic Saprolites: In Situ Experiments Using FTIR Spectroscopy," Geochimica et Cosmochimica Acta, Vol. 73, No. 23, 2009, pp. 7019-7033. doi:10.1016/j.gca.2009.08.031

[8] E. O. Holzbecher, "Modeling Density-Driven Flow in Porous Media: Principles, Numerics, Software," Springer, Berlin, 1998. doi:10.1007/978-3-642-58767-2

[9] D. A. Nield, "Convection in Porous Media," Springer, Berlin, 2006.

[10] M. M. Krol, B. E. Sleep and R. L. Johnson, "Impact of
Low-Temperature Electrical Resistance Heating on Subsurface Flow and Transport," Water Resources Research, Vol. 47, No. 5, 2011.

[11] G. Q. Xu, J. Wang, Y. X. Jin, et al., "Progress in Site Selection for China's High Level Radioactive Waste Repository," Secondary Progress in Site Selection for China's High Level Radioactive Waste Repository, 1995.

[12] M. Z. Min, X. Z. Luo, J. Wang, et al., "Sorption Behavior of U(VI), U-234(VI) and U-238(VI) onto Fracture-Filling Clays in Beishan Granite, Gansu: Application to Selecting the Site of High-Level Radwaste Repository in China," Science in China Series D: Earth Sciences, Vol. 48, No. 10, 2005, pp. 1649-1655. doi:10.1360/03yd0475

[13] Z. X. Sun and Z. S. Zhang, "Geochemical Modeling of Water-Granite Interaction in Beishan Area, NW-China," Geochimica et Cosmochimica Acta, Vol. 72, No. 12, 2008, pp. A917-A917.

[14] Y. H. Dong, G. M. Li and M. Li, "Numerical Modeling of the Regional Ground Water Flow in Beishan Area, Gansu Province," Chinese Science Bulletin, Vol. 54, No. 17, 2009, pp. 3112-3115. doi:10.1007/s11434-009-0344-7

[15] C. J. Lu, C. L. Liu, T. Chen, et al., "Determination of the Effective Diffusion Coefficient for 125I(-) in Beishan Granite," Radiochimica Acta, Vol. 96, No. 2, 2008, pp. 111-117. doi:10.1524/ract.2008.1469

[16] T. Chen, M. Sun, C. Li, et al., "The Influence of Temperature on the Diffusion of (125)I(-) in Beishan Granite," Radiochimica Acta, Vol. 98, No. 5, 2010, pp. 301305. doi:10.1524/ract.2010.1717

[17] C. L. Liu, X. Y. Wang, S. S. Li, et al., "Diffusion of Tc-99 in Granite: A Small Scale Laboratory Simulation Experiment," Radiochimica Acta, Vol. 89, No. 10, 2001, pp. 639-642. doi:10.1524/ract.2001.89.10.639

[18] D. J. Liu, X. H. Fan, J. Yao, et al., "Diffusion of Tc-99 in Granite under Aerobic and Anoxic Conditions," Journal of Radioanalytical and Nuclear Chemistry, Vol. 268, No. 3, 2006, pp. 481-484. doi:10.1007/s10967-006-0194-6

[19] D. Q. Cui and T. Eriksen, "Reactive Transport of Sr, Cs and Tc through a Column Packed with Fracture-Filling Material," Radiochimica Acta, Vol. 82, 1998, pp. 287 292.

[20] H. Vinsova, P. Vecernik and V. Jedinakova-Krizova, "Sorption Characteristics of Tc-99 onto Bentonite Material with Different Additives under Anaerobic Conditions," Radiochimica Acta, Vol. 94, No. 8, 2006, pp. 435440. doi:10.1524/ract.2006.94.8.435

[21] W. Um and R. J. Serne, "Sorption and Transport Behavior of Radionuclides in the Proposed Low-Level Radioactive Waste Disposal Facility at the Hanford Site, Washington," Radiochimica Acta, Vol. 93, No. 1, 2005, pp. 57-63. doi:10.1524/ract.93.1.57.58295

[22] X. K. Wang, X. L. Tan, Q. L. Ning, et al., "Simulation of Radionuclides Tc-99 and Am-243 Migration in Compacted Bentonite," Applied Radiation and Isotopes, Vo. 62, No. 5, 2005, pp. 759-764. doi:10.1016/j.apradiso.2004.10.012

[23] A. Winkler, H. Bruhl, C. Trapp, et al., "Mobility of Technetium in Various Rocks and Defined Combinations 
of Natural Minerals," Radiochimica Acta, Vol. 44-45, 1988, pp. 183-186.

[24] D. W. Oscarson, H. B. Hume and J. W. Choi, "Diffusive Transport in Compacted Mixtures of Clay and Crushed Granite," Radiochimica Acta, Vol. 65, No. 3, 1994, pp. 189-194.

[25] Z. Szanto, E. Svingor, M. Molnar, et al., "Diffusion of H-3, Tc-99, I-125, Cl-36 and Sr-85 in Granite, Concrete and Bentonite," Journal of Radioanalytical and Nuclear Chemistry, Vol. 252, No. 1, 2002, pp. 133-138. doi:10.1023/A:1015256308843

[26] K. H. Lieser and C. Bauscher, "Technetium in the Hydrosphere and in the Geosphere. 1. Chemistry of Technetium and Iron in Natural-Waters and Influence of the Redox Potential on the Sorption of Technetium," Radiochimica Acta, Vol. 42, No. 4, 1987, pp. 205-213.

[27] I. Alliot, C. Alliot, P. Vitorge, et al., "Speciation of Technetium(IV) in Bicarbonate Media," Environmental Science \& Technology, Vol. 43, No. 24, 2009, pp. 91749182. doi:10.1021/es9021443

[28] K. Skagius and I. Neretnieks, "Porosities and Diffusivities of Some Nonsorbing Species in Crystalline Rocks," Water Resources Research, Vol. 22, No. 3, 1986, pp. 389-398. doi:10.1029/WR022i003p00389

[29] M. Zhang and M. Takeda, "Theoretical Evaluation of the
Through-Diffusion Test for Determining the Transport Properties of Geologic Materials," WM'05 Conference, Tucson, 27 February-3 March 2005.

[30] M. H. Bradbury and A. Green, "Measurement of Important Parameters Determining Aqueous Phase Diffusion Rates through Crystalline Rock Matrices," Journal of Hydrology, Vol. 82, No. 1-2, 1985, pp. 39-55. doi:10.1016/0022-1694(85)90045-9

[31] K. B. Harvey, "Measurement of Diffusive Properties of Intact Rock," 1996, p. 97.

[32] R. Mills and V. M. M. Lobo, "Self-Diffusion in Electrolyte Solutions: A Critical Examination of Data Compiled from the Literature," 1989, p. 3.

[33] J. A. Dean, "Lange's handbook of chemistry," 13th Edition, McGraw-Hill, New York, 1985.

[34] H. Sato, M. Yui and H. Yoshikawa, "Ionic Diffusion Coefficient of $\mathrm{Cs}^{+}, \mathrm{Pb}^{2+}, \mathrm{Sm}^{3+}, \mathrm{Ni}^{2+}, \mathrm{Se}_{4}^{2-}$ and $\mathrm{TcO}_{4}^{-}$in Free Water Determined from Conductivity Measurements," Journal of Nuclear Science and Technology, Vol. 33, No. 12, 1996, pp. 950-955. doi:10.1080/18811248.1996.9732037

[35] J. S. Liu, L. Martin and I. Neretnieks, "Data and Uncertainly Assessment: Matrix Diffusivity and Porosity in Situ,” SKB R-06-111, Blekholmstorget, 2006. 